\title{
Improved methods for mass production of magnetosomes and applications: a review
}

\author{
Abdul Basit ${ }^{1,2}$, Jiaojiao Wang ${ }^{1}$, Fangfang Guo ${ }^{3}$, Wei Niu ${ }^{1}$ and Wei Jiang ${ }^{1 *}$ (1)
}

\begin{abstract}
Magnetotactic bacteria have the unique ability to synthesize magnetosomes (nano-sized magnetite or greigite crystals arranged in chain-like structures) in a variety of shapes and sizes. The chain alignment of magnetosomes enables magnetotactic bacteria to sense and orient themselves along geomagnetic fields. There is steadily increasing demand for magnetosomes in the areas of biotechnology, biomedicine, and environmental protection. Practical difficulties in cultivating magnetotactic bacteria and achieving consistent, high-yield magnetosome production under artificial environmental conditions have presented an obstacle to successful development of magnetosome applications in commercial areas. Here, we review information on magnetosome biosynthesis and strategies for enhancement of bacterial cell growth and magnetosome formation, and implications for improvement of magnetosome yield on a laboratory scale and mass-production (commercial or industrial) scale.
\end{abstract}

Keywords: Magnetosome biosynthesis, high-yield, cell growth, culture conditions, commercial applications

\section{Introduction}

The research interest of nanoparticles applications in the fields of biomedical, biotechnology and environmental protection has gained tremendous importance in recent years. The development of magnetic nanoparticles is the outcome of that investigative focus and significance [1]. The physico-chemical procedures for the preparation of magnetic nanoparticles involve high cost and chemicals with environmental implications and human health hazards. Thus, the need arises to ascertain and use environmental friendly, biocompatible, cheap, and low energy demanding methods for preparation of nano-particles [2]. In this situation, the nano-particles synthesized by magnetotactic bacteria with distinctive characteristics would be right choice and requisite for biomedical and biotechnology applications [3]. Magnetosomes, which consist of membrane-enveloped, nano-sized magnetite $\left(\mathrm{Fe}_{3} \mathrm{O}_{4}\right)$ or greigite $\left(\mathrm{Fe}_{3} \mathrm{~S}_{4}\right)$ crystals arranged in chain-like

\footnotetext{
*Correspondence: jiangwei01@cau.edu.cn

1 State Key Laboratory of Agro-Biotechnology, College of Biological Sciences, China Agricultural University, Beijing 100193, China

Full list of author information is available at the end of the article
}

structures, are synthesized by a variety of magnetotactic bacteria [4]. Many recent studies have involved cultured magnetotactic bacterial strains, particularly Magnetospirillum gryphiswaldense MSR-1, Magnetospirillum magneticum AMB-1, Magnetospirillum magnetotacticum MS-1 and Magnetospirillum sp. ME-1 [5, 6]. Investigations of these strains have greatly increased our understanding of molecular mechanisms of magnetotactic bacteria in general [5]. Chemical composition, morphology, and size of magnetite crystals are uniform within a given strain, but differ among strains of magnetotactic bacteria. Magnetite and greigite crystals of magnetosomes generally display constant shape, although slight variations of size and shape are sometimes observed for greigite [7].

Considerable research effort has therefore been focused on production of high-quantity magnetosomes [8, 9]. However, their cultivation under experimental conditions has been difficult because of their highly precise and restricted living conditions [10]. Isolation, identification, and characterization of magnetosomes are generally at an early research stage. The major obstacle to massproduction (commercial or industrial) scale cultivation/

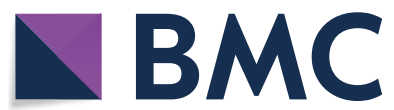

(c) The Author(s) 2020. This article is licensed under a Creative Commons Attribution 4.0 International License, which permits use, sharing, adaptation, distribution and reproduction in any medium or format, as long as you give appropriate credit to the original author(s) and the source, provide a link to the Creative Commons licence, and indicate if changes were made. The images or other third party material in this article are included in the article's Creative Commons licence, unless indicated otherwise in a credit line to the material. If material is not included in the article's Creative Commons licence and your intended use is not permitted by statutory regulation or exceeds the permitted use, you will need to obtain permission directly from the copyright holder. To view a copy of this licence, visit http://creativeco mmons.org/licenses/by/4.0/. The Creative Commons Public Domain Dedication waiver (http://creativecommons.org/publicdomain/ zero/1.0/) applies to the data made available in this article, unless otherwise stated in a credit line to the data. 
growth of magnetotactic bacteria (MSR-1, AMB-1, MS-1 and ME-1) is the need for high magnetosome yield at reasonable expense and energy cost [11, 12]. In theory, magnetosome yield can be improved through modification (optimization) of culture medium composition and growth conditions [12, 13]. However, few studies have focused on such optimization. Effects on growth of changes in factors such as temperature, $\mathrm{pH}$, dissolved oxygen concentration, and concentrations of various salts and acids have repeatedly been investigated, but greater emphasis is needed on maximization of magnetosome yield [12]. Here, we review information on magnetosome biosynthesis and strategies used for enhancement of bacterial cell growth and magnetosome formation, and implications for improvement of magnetosome yield on a laboratory scale and mass-production (commercial or industrial) scale.

\section{Mass production of magnetosomes}

Mass production of magnetosomes for commercial applications remains a challenging task. Cultivation of magnetotactic bacteria (MSR-1, AMB-1, MS-1) is difficult because of their diverse metabolisms, although several types of culture media have been developed for high magnetosome yield [14]. MSR-1 has been utilized extensively as a model microorganism for studies of magnetosome formation. Growth conditions affect the physical properties of magnetosomes synthesized by MSR-1. In particular, depending on the bacterial growth phase (either at the logarithmic phase or at the stationary phase), the magnetosomes present differences in size and stoichiometry [8]. Optimal culture conditions (in regard to dissolved oxygen concentration, $\mathrm{pH}$, nutrient composition, and salt concentrations) are highly restrictive. A variety of control strategies have been evaluated for achieving more efficient magnetosome yield. Optimized culture conditions for growth of MSR-1, based on studies to date, are summarized in Fig. 1.

\section{Factors affecting the mass production of magnetosomes}

\section{Nutrient-balanced feeding}

The major factor affecting growth of magnetotactic bacteria, and consequently magnetosome formation, is concentration of nutrients, particularly carbon source. It was not possible to extend optimized medium conditions determined for MSR-1 growth in shake-flask culture directly to mass-production scale fermentor culture [15]. During MSR-1 culture, accumulation of excessive nutrients and inhibitory components in medium exerts ratelimiting effects on cell growth. According to Liebig's Law of the Minimum, biomass in a given system is typically restricted by the amount of one particular nutrient, even when other nutrients are present in excess [16].

A nutrient-balanced feeding strategy can reduce the inhibitory effect of excessive amount of nutrients in medium. In this strategy, accumulation of $\mathrm{Na}^{+}$and $\mathrm{Cl}^{-}$ ions is reduced by replacement of carbon and nitrogen sources. In fed-batch culture, accumulation of $\mathrm{Na}^{+}$and $\mathrm{Cl}^{-}$ions decreases osmotic potential and consequently

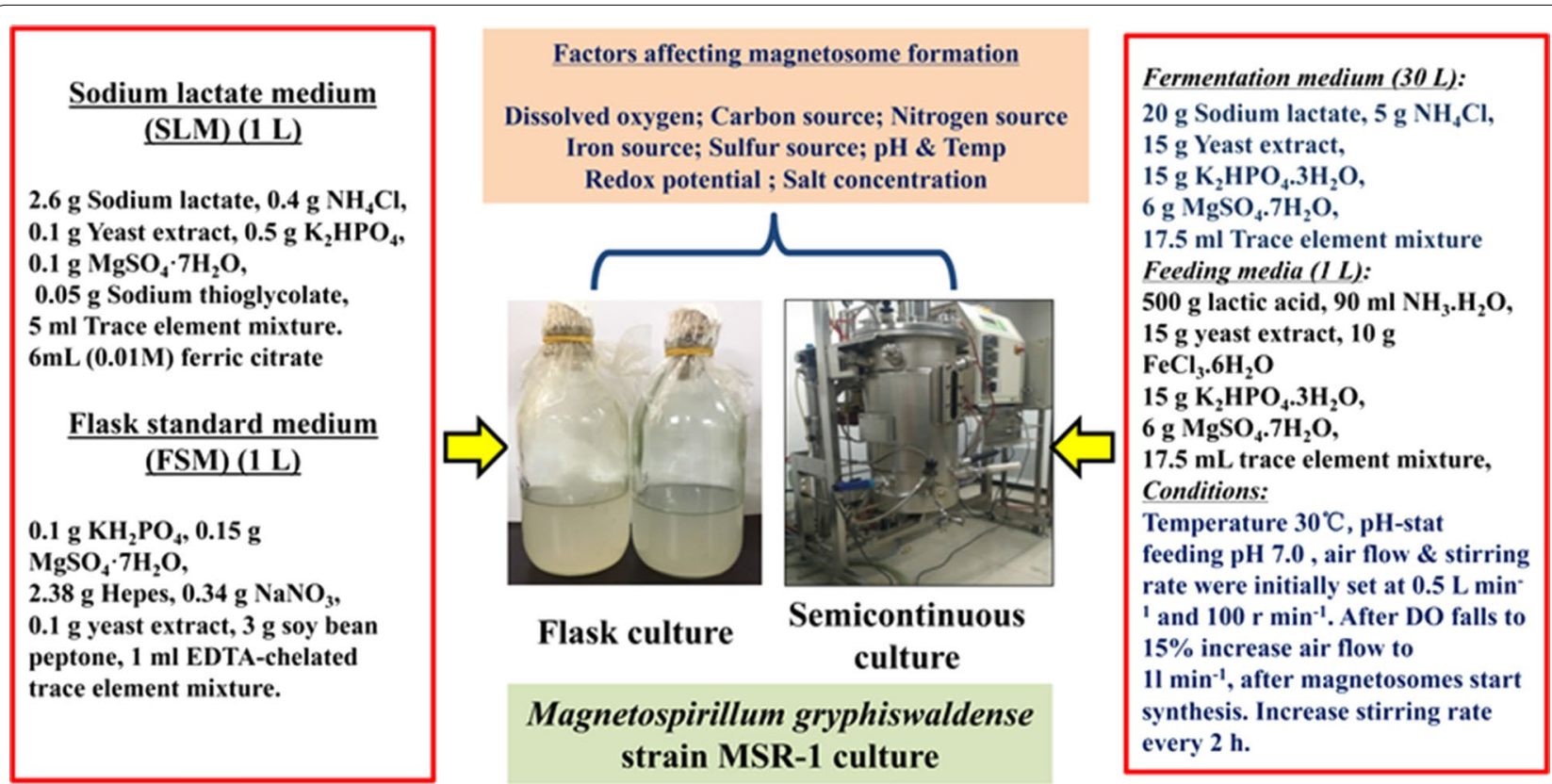

Fig. 1 Culture media used for cultivation of M. gryphiswaldense strain MSR-1, and factors that affect MSR-1 growth [15] 
inhibits cell growth. Even a low $\mathrm{NaCl}$ concentration (40 $\mathrm{mM}\left[2.34 \mathrm{~g} \mathrm{~L}^{-1}\right]$ ) inhibited cell growth [17]. Thus, a nutrient-balanced feeding strategy can significantly enhance growth rate.

Liu et al. [15], established a "chemostat culture" technique for MSR-1 cultivation based on $\mathrm{pH}$-stat feeding to maintain consistency of nitrogen, carbon, and iron concentrations using several organic acids. Microaerobic conditions were applied for MSR-1 cultivation in a fed-batch autofermentor system. A nutrient solution containing (per liter) ferric citrate $(4.2 \mathrm{~g})$, lactic acid $(52.6 \mathrm{~g})$, sodium lactate $(129 \mathrm{~g})$, and $\mathrm{NH}_{4} \mathrm{Cl}(54.9 \mathrm{~g})$ was used for $\mathrm{pH}$-stat feeding. High values of magnetosome yield $\left(83.23 \pm 5.36 \mathrm{mg} \mathrm{L}^{-1}\right)$ and cell growth $(55.49 \mathrm{mg}$ $\mathrm{L}^{-1}$ day $^{-1}$ ) were achieved at low sodium lactate level (Table 1). Chemostat culture technique efficiently promotes magnetosome yield and cell growth with low time and energy cost. Cytotoxic effects were observed for excessive dissolved oxygen concentration ( $\geq 20 \mathrm{ppb}$ ) and presence of lactic acid in medium. Artificial control strategies for autofermentor systems must be adjusted in regard to physiological condition of cells. Similarly, Fernández-Castané et al. [18], demonstrated the pHstat fed-batch growth strategy. In this strategy various concentrations of the lactic acid (carbon source) and sodium nitrate (electron acceptor) were applied in the feed. Growth conditions and intracellular iron concentration were optimized according to the biomass concentration. The highest biomass concentration reached to $\mathrm{OD}_{565 \mathrm{~nm}}=15.50$ [18].
MSR-1 cell growth and magnetosome formation are high when sodium lactate is used as carbon source. On the other hand, low sodium lactate concentration is needed to maintain low dissolved oxygen concentration for rapid cell growth and magnetosome formation [15]. Maintaining sodium lactate concentration in mass production scale-up is difficult, and specific feeding strategies are therefore required in the laboratory. $\mathrm{NH}_{4} \mathrm{Cl}$ has been shown to be a better nitrogen source than $\mathrm{NaNO}_{3}$ $[15,17]$.

Zhang et al. [17], achieved maximal magnetosome yield in MSR-1 using a semi-continuous culture strategy. Optimized flask medium was used in 7.5- and 42-L autofermentors, nutrient-balanced feeding strategy was applied, and carbon and nitrogen sources were replaced to reduce accumulation of $\mathrm{Na}^{+}$and $\mathrm{Cl}^{-}$ions. Osmotic potential was decreased by $\mathrm{Na}^{+}$and $\mathrm{Cl}^{-}$ion accumulation, thereby inhibiting magnetosome yield and cell growth. We achieved maximal values in fed-batch culture of magnetosome yield $356.52 \mathrm{mg} \mathrm{L}^{-1}$ and cell growth $9.16 \mathrm{~g} \mathrm{~L}^{-1}$ [17] (Table 1).

Yang et al. [19], cultured AMB-1 cells in magnetic spirillum growth medium (MSGM) enriched with L-cysteine, yeast extract, and polypeptone. In this system, L-cysteine enhanced cell growth and reduced lag phase, resulting in high magnetosome production. The addition of only yeast extract and polypeptone results in slightly production of magnetosomes. Yeast extract displays no significant effect in magnetosome production, whereas polypeptone only increases the final cell density [20]. The reason for improved production of

Table 1 Yield production of magnetosomes by magnetotaic bacteria and their conditions

\begin{tabular}{|c|c|c|c|c|c|}
\hline Strains & Growth Media & $\mathrm{pH}$ and Temperature & Dissolved oxygen & Yield production & References \\
\hline ME-1 & OFM & 7.0 and $30{ }^{\circ} \mathrm{C}$ & $0.5 \mathrm{ppm}$ & $120 \mathrm{mg} \mathrm{L}^{-1}$ & [6] \\
\hline MS-1 & MSGM + PEG & 7.0 and $28^{\circ} \mathrm{C}$ & $1 \%$ & $21.8 \mathrm{mg} \mathrm{L}^{-1}$ & [11] \\
\hline MSR-1 & OFM & 6.8 and $30^{\circ} \mathrm{C}$ & $0 \mathrm{ppm}$ & $\begin{array}{l}83.23 \pm 5.36 \\
\mathrm{mg} \mathrm{L}^{-1}\end{array}$ & [15] \\
\hline MSR-1 & $\begin{array}{l}\text { OFM } \\
\text { (feed batch) }\end{array}$ & 6.9 and $30^{\circ} \mathrm{C}$ & 0-1 ppm & $225.53 \mathrm{mg} \mathrm{L}^{-1}$ & [17] \\
\hline MSR-1 & $\begin{array}{l}\text { OFM } \\
\text { (semi-continuous) }\end{array}$ & 6.9 and $30^{\circ} \mathrm{C}$ & 0-1 ppm & $\begin{array}{l}168.3 \mathrm{mg} \mathrm{L}^{-1} \\
\text { (dry weight basis) }\end{array}$ & [17] \\
\hline AMB-1 & MSGM & 6.7 and $25^{\circ} \mathrm{C}$ & - & $7.5 \mathrm{mg} \mathrm{L}^{-1}$ & [19] \\
\hline MSR-1 & OCM & 6.8 and $30^{\circ} \mathrm{C}$ & 5-10 ppm & $186.67 \mathrm{mg} \mathrm{L}^{-1}$ & [23] \\
\hline AMB-1 & LSM & 7.0 and $28^{\circ} \mathrm{C}$ & $0.25 \mathrm{mbar}$ & $3.3 \mathrm{mg} \mathrm{L}^{-1}$ & [25] \\
\hline MSR-1 & LSM & 7.0 and $28^{\circ} \mathrm{C}$ & $0.25 \mathrm{mbar}$ & $6.3 \mathrm{mg} \mathrm{L}^{-1}$ & [25] \\
\hline MSR-1 & OFM & 7.0 and $30^{\circ} \mathrm{C}$ & $0.5 \%$ & $58.4 \pm 6.4 \mathrm{mg} \mathrm{L}^{-1}$ & [31] \\
\hline AMB-1 & MSGM & 6.7 and $26^{\circ} \mathrm{C}$ & - & $4.5 \mathrm{mg} \mathrm{L}^{-1}$ & [90] \\
\hline MSR-1 & OGM & 6.8 and $30^{\circ} \mathrm{C}$ & $>1 \mathrm{ppm}$ & $\begin{array}{l}26 \pm 3 \\
\text { Magnetosomes no. }\end{array}$ & [91] \\
\hline
\end{tabular}


magnetosomes by L-cysteine is unknown, however, it is assumed that magnetosome production is not associated with lower redox potentials in the presence of L-cysteine [20]. Moreover, AMB-1 can grow without available amino acids and L-cysteine synthesis pathways in AMB-1 may be not efficient or related to cell growth. Therefore, AMB-1 may directly use L-cysteine instead of having to synthesize it for facilitating cell growth [20].

Ke et al. [6], cultured Magnetospirillum sp. ME-1 in growth medium enriched with sodium acetate, sodium succinate, yeast extract, $\mathrm{MgSO}_{4}, \mathrm{NH}_{4} \mathrm{Cl}$ and ferric citrate. ME-1 utilizes carbon source for growth such as succinate, fumarate, oxaloacetate, pyruvate, acetate, lactate, malate and peptone. In addition, ME- 1 can grow in the absence of nitrogen source, however, $\mathrm{NH}_{4} \mathrm{Cl}$ or $\mathrm{NaNO}_{3}$ supplementation enhance the ME-1 growth. ME-1 exhibit urease and oxidase activity, suggesting the capability of aerobic growth, however, aerobic condition inhibits the magnetosome formation in ME-1 [6]. Fed-batch fermentation of ME-1 was optimized at a constant level of $\mathrm{pH} 6.8$ in a 10-L fermenter based on $\mathrm{pH}$-static feeding, while supplying the carbon, nitrogen and iron sources for large-scale production [6] (Table 1).

Despite the high yield of magnetosomes, such developed methods for the growth of magnetotactic bacteria contains toxic components in growth medium. These components include carcinogenic, mutagenic and reprotoxic chemicals, heavy metals, chelating agents and un characterized animal derived ingredients such as yeast extract [21]. There is a great need to obtain large scale production of pure magnetosomes with lowest possible amount of such impurities or toxic components (other metals than iron). Therefore, Berny et al. [22], developed a minimal growth medium for magnetosomes production with less or devoid of toxic components, and having similar magnetosome properties as those obtained in the best reported growth conditions by Zhang et al. [17]. Firstly, magnetotactic bacteria were amplified in pre-growth medium [containing sodium lactate $(2.6 \mathrm{~g})$, $\mathrm{NH}_{4} \mathrm{Cl}(0.4 \mathrm{~g}), \mathrm{MgSO}_{4} \cdot 7 \mathrm{H}_{2} \mathrm{O}(0.1 \mathrm{~g}), \mathrm{K}_{2} \mathrm{HPO}_{4}(0.1 \mathrm{~g})$, thiamin $\mathrm{HCl}(40 \mu \mathrm{g})$, ME6 $(0.5 \mathrm{~mL})]$ without producing magnetosomes [22]. In second step, magnetotactic bacteria were then fed with an iron rich fed-batch medium containing [sodium lactate $(1.3 \mathrm{~g}), \mathrm{NH}_{4} \mathrm{Cl}$ $(0.2 \mathrm{~g}), \mathrm{MgSO}_{4} \cdot 7 \mathrm{H}_{2} \mathrm{O}(0.03 \mathrm{~g}), \mathrm{K}_{2} \mathrm{HPO}_{4}(0.03 \mathrm{~g})$, thiamin $\mathrm{HCl}(27 \mu \mathrm{g})$, of ME6 $(0.08 \mathrm{~mL})]$ to allow magnetosome synthesis [22]. After $50 \mathrm{~h}$ of growth, biomass concentration reached to $\mathrm{OD}_{565 \mathrm{~nm}}=8$ and yield magnetosomes production of about $10 \mathrm{mg} / \mathrm{L}$ of growth medium. A significant reduction/disappearance in magnetosome composition of $\mathrm{Zn}, \mathrm{Mn}, \mathrm{Ba}$, and $\mathrm{Al}$ were observed [22]. This new strategy for the magnetosomes production without or lowest concentration of impurities other than iron, paves the way towards medical applications.

\section{Dissolved oxygen concentration}

Magnetosome biosynthesis requires microaerobic or anoxic conditions. Low dissolved oxygen level significantly affects cell growth because high-density culture requires high dissolved oxygen to obtain desired magnetosome yield. On the other hand, increased dissolved oxygen may increase MSR-1 density in culture medium but inhibit magnetosome formation [15]. A conflict thus exists between magnetosome formation and cell growth, making it difficult to simultaneously achieve high MSR-1 cell density and high magnetosome yield. This conflict may be resolved somewhat by controlling dissolved oxygen to an optimal level through adjustment of cell growth rate. Jajan et al. [23], reported the reduced iron uptake and magnetosomes production at the dissolved oxygen level of above 5-10 ppm. However, when dissolved oxygen was lower than 5-10 ppm, iron uptake rate and production of magnetosomes was increased, which probably due to the slow growth of bacteria [23]. Sun et al. [24], established mass culture of MSR-1 for enhanced magnetosome production in a 42-L fermentor, with optimized flask medium, by applying strict microaerobic conditions (near-zero dissolved oxygen concentration) and using ferric citrate and sodium lactate as iron and carbon sources in medium. This strategy was effective for yield cultivation of magnetosomes because cell growth was regulated at low dissolved oxygen concentration, resulting in high magnetosome yield.

AMB-1 is a facultative anaerobic magnetotactic bacterium that transfers electrons via two respiratory pathways. Under aerobic growth conditions, AMB-1 utilizes oxygen as electron acceptor and neither promotes nor inhibits formation of magnetic particles. In an alternative pathway, AMB-1 uses nitrate as electron acceptor and therefore requires low media redox potentials, which are conducive to magnetosome formation. In a study by Yang et al. [20], magnetosome production rate was high under low dissolved oxygen concentration in liquid phase. When dissolved oxygen concentration in liquid phase exceeded a certain level $(0.20 \mathrm{ppm})$, the respiratory pathway shifted to aerobic growth, leading to reduced magnetosome production.

Dissolved oxygen concentration is strongly affected by air flow rate and stirring rate. When dissolved oxygen during initial growth phase is raised by increasing air flow and stirring rates, magnetosome yield remains low until dissolved oxygen declines to an undetectable level. To overcome this phenomenon in MSR-1 cultivation, dissolved oxygen must be enhanced to an optimal level by stirring, and cells then allowed to reduce dissolved 
oxygen through respiration, until reaching the level optimal for magnetosome formation. High magnetosome production was achieved by optimizing/ adjusting air flow and stirring rates [15]. During initial culture phase, dissolved oxygen was reduced by maintaining these rates respectively at $1 \mathrm{~L} \mathrm{~min}^{-1}$ and $200 \mathrm{rpm} \mathrm{min}{ }^{-1}$. During later culture phase, dissolved oxygen was increased by adjusting air flow rate to $2 \mathrm{~L} \mathrm{~min}^{-1}$ at $20 \mathrm{~h}$ and stirring rate to $300 \mathrm{rpm} \mathrm{m^{-1 }}$ at $28 \mathrm{~h}$. Under these conditions, cells grew rapidly, dissolved oxygen become undetectable at $12 \mathrm{~h}$, and cell density reached $\mathrm{OD}_{565 \mathrm{~nm}}=12.3$ at 36 h. Sodium lactate and ferric citrate concentrations were controlled respectively in the ranges $3-6 \mathrm{mmol} \mathrm{L}^{-1}$ and $70-110 \mu \mathrm{mol} \mathrm{L}{ }^{-1}$ during the process. High values of magnetosome yield $\left(83.23 \pm 5.36 \mathrm{mg} \mathrm{L}^{-1}\right)$ and productivity (55.49 $\mathrm{mg} \mathrm{L}^{-1}$ day $\left.^{-1}\right)$ were thus attained [15] (Table 1).

In ME-1 cultivation, dissolved oxygen was controlled to enhance the magnetosome production at a constant level of $0.5 \%$ by coupling to the air-flow rate and stirring rate. During fed-batch fermentation, a stirring rate (in the range of 50-300 rpm) produced a large amount of magnetosomes at constant level of dissolved oxygen (0.5\%). The resulting cell density and magnetosome yield at $49 \mathrm{~h}$ were $6.5\left(\mathrm{OD}_{565}\right)$ and $120 \mathrm{mg} \mathrm{L}^{-1}$ (wet weight). This strategy attained high magnetosome yield and productivity, thus indicate that ME-1 has great potential for the largescale production of magnetosomes [6].

Low dissolved oxygen levels have been established empirically in many studies, but without continuous measurement of dissolved oxygen concentration or definition of its control in the medium. Heyen and Schüler [25], established a method for automatic control of low oxygen tension $\left(\mathrm{pO}_{2}\right)$ in MSR-1 culture medium using a fermentor system for oxystat operation. $\mathrm{pO}_{2}$ tension was correlated with magnetite formation. The lowest recorded $\mathrm{pO}_{2}$ value $\left(0.25 \mathrm{mbar} ; 1 \mathrm{bar}=10^{5} \mathrm{~Pa}\right)$ was the most favorable for magnetosome formation. Cells grown under oxystat conditions showed significantly higher magnetite yield (6.3 $\mathrm{mg} \mathrm{L}^{-1}$ day $^{-1}$ ) (Table 1$)$.

\section{Ferric ion uptake}

Iron is required as a cofactor for many enzymes, particularly those involved in major biological pathways. Specific iron transport mechanisms in cells provide iron levels sufficient for optimal growth. Some bacteria produce ferric chelators (termed siderophores) to take up ferric iron $\left(\mathrm{Fe}^{3+}\right)$. Magnetotactic bacteria synthesize magnetosomes composed of magnetite or greigite after finding microaerophilic conditions suitable for their growth [26]. In MSR-1, magnetite is the major component of magnetosomes, and magnetosome production is therefore not significantly affected by ferric citrate concentration in culture medium. Jajan et al. [23], showed that ferrous sulfate was a better source of iron than ferric quinate and ferric citrate for M. gryphiswaldense [23]. In a study of AMB-1, Yang et al. [19], used various ferrous sulfate and ferric chelates as iron sources, and compared their effects. Magnetosome production was significantly enhanced by ferric gallate and sulfate, and was also affected by other iron source (ferric quinate, ferric malate), and by iron uptake rate.

Ferric ion $\left(\mathrm{Fe}^{3+}\right)$ is taken up during dynamic cell growth, and the amount taken up is correlated with magnetosome formation when dissolved oxygen level in medium is undetectable. Magnetosome formation requires micromolar iron concentration and microoxic conditions [27]. MSR-1 cells are nonmagnetic under oxic conditions, but begin to produce magnetite when dissolved oxygen concentration falls below a threshold value (20 mbar or undetectable). In log phase of cell growth, ferric ion is taken up rapidly, and its absorption rate is $>80 \%$ and correlated with magnetosome formation [15].

\section{Magnetosome synthesis consumes ATP}

ATP is the universal energy source required for metabolism, molecular transportation, signal transduction, and other crucial cell physiological processes. Magnetosome synthesis requires a large amount of energy, and iron uptake depends on ATP availability. NADH provides a proton gradient across the inner mitochondrial membrane for ATP production catalyzed by ATP synthase [28]. NADH/NAD ${ }^{+}$ratio increases rapidly following magnetosome maturation during log phase.

Reducing power increases significantly during magnetosome synthesis; however, excessive reducing power may inhibit magnetosome synthesis and cell growth [17]. MSR-1 can consume excessive reducing power through polyhydroxybutyrate (PHB) synthesis and hydrogen release [29]. MSR-1 cells contain PHB granules [30]. Knockout of PHB synthase gene in MSR-1 resulted in $\sim 30 \%$ increase of magnetosome number [31]. Energy competition thus occurs between PHB and the magnetosome synthesis process. A mutant of ATPase gene of MSR and MSR-NPHB created by conjugation was used as a genetic engineering tool to demonstrate that chloramphenicol acetyltransferase (CAT) promoter increases downstream expression of ATPase gene. In comparison with MSR-1, MSR-NPHB displayed 35\% greater hydrolysis activity, 71\% lower PHB accumulation, 56\% greater oxygen consumption, and $40 \%$ greater lactate consumption. Maximal yield of MSR-NPHB in a 7.5-L bioreactor was $58.4 \pm 6.4 \mathrm{mg} \mathrm{L}^{-1}$ [31]. These findings demonstrate that magnetosome yield can be enhanced, and production cost and time reduced, through genetic 
manipulation of MSR-1 in combination with optimization/modification of culture and growth media.

\section{Superoxide dismutase activity}

Magnetosome synthesis is associated with in vitro breakdown of $\mathrm{H}_{2} \mathrm{O}_{2}$, and with protective effects against $\mathrm{H}_{2} \mathrm{O}_{2}$ toxicity in cells. In microorganisms, the enzyme superoxide dismutase breaks down $\mathrm{H}_{2} \mathrm{O}_{2}$ and superoxide anion radical $\left(\mathrm{O}_{2}^{-}\right)$, both of which have destructive effects on cell macromolecules [32]. In magnetotactic bacteria, superoxide dismutase also reduces oxidative stress during magnetosome formation. $\mathrm{H}_{2} \mathrm{O}_{2}$ may form a hydroxyl radical after receiving an electron from ferrous iron $\left(\mathrm{Fe}^{2+}\right)$. Hydroxyl radical is the reactive oxygen species (ROS) that can damage biomolecules [33]. Yang et al. [30], demonstrated that when sufficient dissolved oxygen and nutrients are available in late log phase, magnetosome formation and maturation are unable to catch up to cell division rate, leading to dilution of magnetosomes. Reduction of superoxide dismutase activity may thus result from similarity of diluted ROS. Magnetosomes, as well as artificial magnetic nanoparticles, participate in scavenging of ROS [27, 34], and this activity may also lead to reduced superoxide dismutase activity.

\section{Rapid large-scale purification of magnetosomes}

Improved and optimized methods for extraction and purification of magnetosomes are needed, for reasons mentioned in Introduction. Magnetosome extraction methods have been described in numerous publications [35-37]. However, methods described to date for magnetosome purification, which involve disruption of cells by sonication, washing with PBS buffers, ultrasonic bathing, and collection of magnetosomes using a magnet (Fig. 2A), are not suitable for large-scale systems. Guo et al. [36], developed a rapid, continuous system for largescale magnetosome purification. The system involved a high-pressure homogenizer, a magnetic isolation system (MIS), ultrasonic and electro-elution equipment, and magnetic stirring (Fig. 2B). The MIS consisted of an ultrasonic tank, a permanent magnet, and a magnetic isolation column. The magnetic isolation column was a plastic cylinder filled with iron beads (diameter 4-6 mm), with four interfaces (inlet or outlet) at the two ends. The two interfaces at the bottom end carried buffer and solution containing cells/ magnetosomes. The two interfaces at the top end carried buffer and discharged wastewater. The buffers used in the MIS were sterilized by heating at $121^{\circ} \mathrm{C}$ for $20 \mathrm{~min}$, and the magnetic isolation column was cleaned before use by pumping through a $75 \%$ ethanol solution $(\mathrm{v} / \mathrm{v})$. The high-pressure homogenizer and MIS were prewetted with one bed-volume of PBS buffer. Culture solution mixed with buffer was used to lyse cells in the homogenizer, and cell extract was pumped into the MIS. Solution at controlled flow rate was passed through the homogenizer, lysed solution was pumped into the MIS, and waste residue was discharged through the outlet. Magnetosomes in the MIS were washed with six bed-volumes of buffer containing various concentrations of urea, and then washed into the ultrasonic tank by ultrasonication process. Urea solution in the ultrasonic tank was replaced by the buffer, magnetosomes were dispersed by ultrasonication, and buffer and magnetosome solution were simultaneously pumped back into the MIS by operating pumps. After binding of magnetosomes by magnetic force, six bed-volumes of buffer were pumped into the MIS. Ultrasonication was activated and magnet removed in the MIS such that magnetosomes were released and washed back into the ultrasonic tank. The above procedure was repeated three or four times until proteins in waste solution were undetectable at $\mathrm{OD}_{280}$.

The industrial development of magnetosomes has been raised by high yield magnetosome production methods. However, magnetotactic bacterium are Gram-negative bacteria, which contains bacterial endotoxin such lipopolysaccharides [38], that probably effect magnetosomes applications. Therefore, several studies revealed the production of sterile or endotoxin free magnetosomes by removing of surrounding biological materials from magnetosomes mineral core $[38,39]$. Since magnetosome formation results from the invagination of the bacterial membrane, the endotoxin concentration at the magnetosome surface might be higher than the tolerated concentration. Therefore, followed by the extraction and purification of magnetosomes from magnetotactic bacteria, organic materials such as endotoxins can be removed with the treatment of different detergents (SDS, Triton $\mathrm{X} 100$, phenol and chloroform) at $60^{\circ} \mathrm{C}$ in the presence of sonication [39]. The obtained uncoated magnetosome minerals can be characterized by transmission electron microscope (TEM). The detection and quantification of endotoxin concentration of uncoated magnetosome minerals can further be estimated by limulus amebocyte lysate (LAL) assay. Deduced endotoxin concentration can be further verified by in vivo experiments. Hamdous et al. [38], in their study, examined the endotoxin concentrations by administering the purified magnetosome suspension in the rabbits' ear. The induction of any fever among rabbits was indicated the pyrogenic or non-pyrogenic suspensions.

\section{Applications}

Magnetosomes are of considerable research and practical interest because of unique features such as narrow size distribution, uniform morphology, high chemical purity, low toxicity, and membrane envelope 


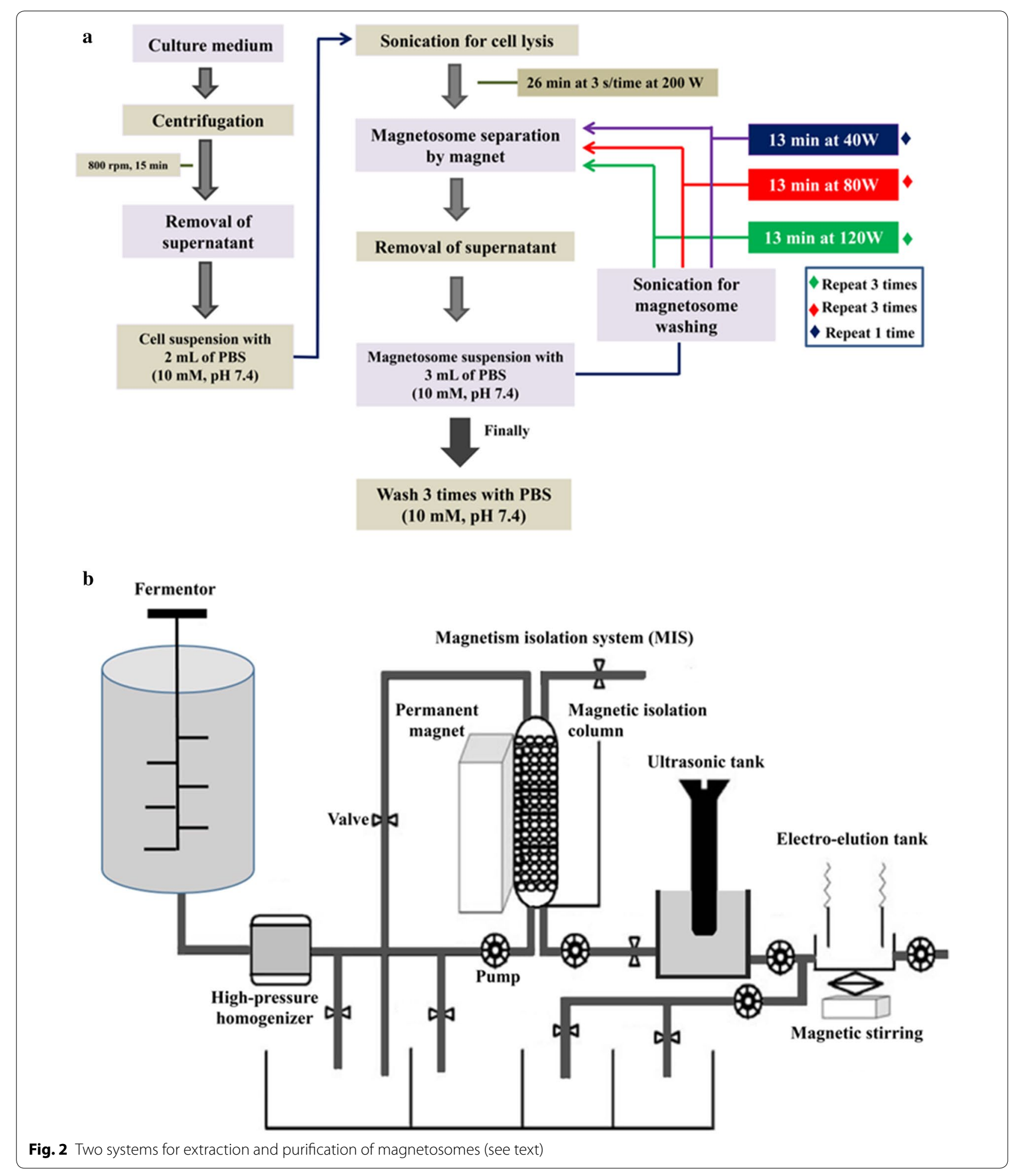

[37]. Applications of magnetosomes reflect their distribution, ferrimagnetic properties, nanoscale size, membrane-bound structure, and dispersal ability. Applications of magnetosomes are summarized in
Fig. 3. Recent studies demonstrated that purified, sterilized MSR-1 magnetosomes are nontoxic to cancer cells in vitro, suggesting their potential application as drug carriers for clinical treatment of cancer and other 
Magnetic Bacteria Applications
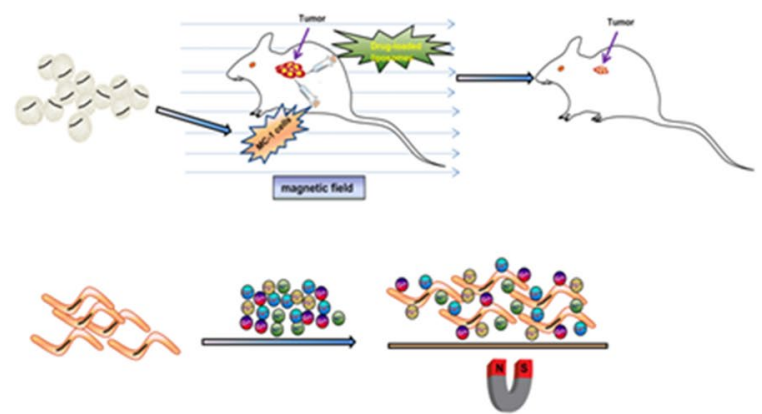

Magnetosomes Applications-Nucleic Acid Detection Magnetosomes Applications-Oncotherapy
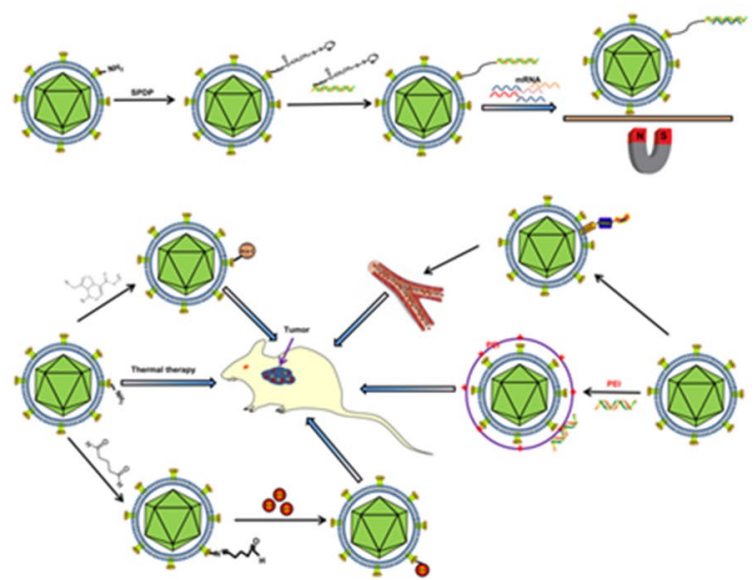

Fig. 3 Schematic representation of magnetosomes applications

diseases [35, 40-42]. Magnetosome membranes contain proteins and active groups that can function as binding sites. Synthetic magnetic nanoparticles utilize specific active surface groups, through either chemical coupling or physical adsorption. Because of the presence of a natural phospholipid membrane, coupling of magnetosomes with active substances such as chemotherapeutic drugs $[37,43]$ and peptides [40] is of great interest in biomedicine and drug delivery [44-50]. Magnetosomes wrapped with polyethyleneimine (PEI) can be used in gene delivery and cancer treatment [51-53]. Magnetosomes extracted from magnetotactic bacteria can be used as a magneto-thermal therapy for cancer treatment [54-56]. Other practical applications of magnetosomes includes as magnetic resonance imaging (MRI) probe or modified with protein for tumor detection $[57,58]$, the tracking of stem cells,
Magnetosomes Applications-Bacterial And Virus Detection

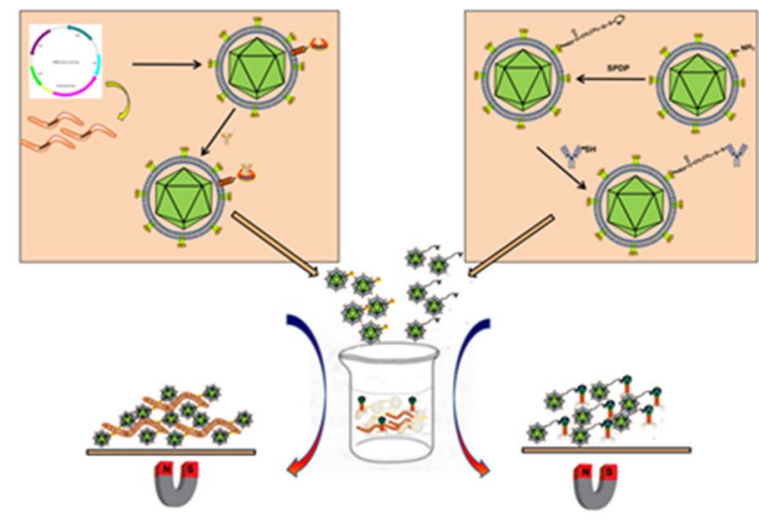

Magnetosomes Other Applications

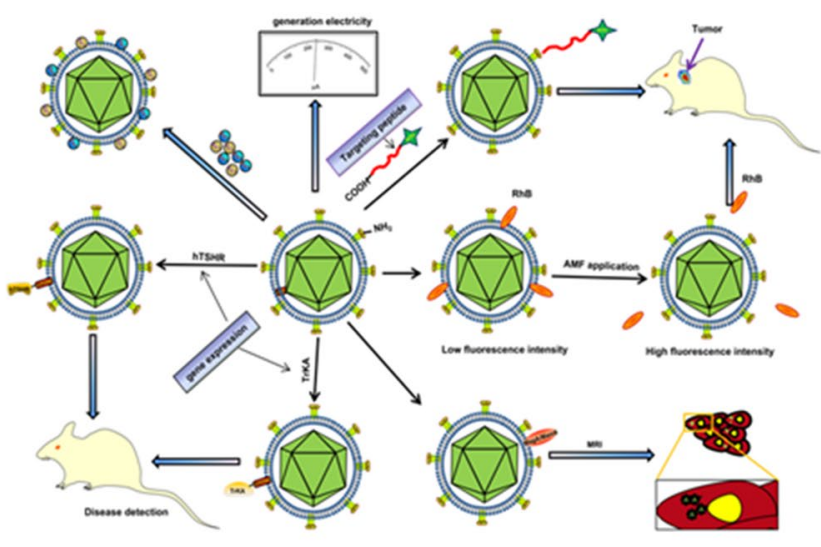

dendritic cells and single nucleotide polymorphism (SNP) $[59,60]$, detection of pathogenic bacteria, viruses [61-63] and other immunodetection [64, 65], discrimination or recovery of DNA and mRNA [59, 66-68], adsorption and mineralization of metals [69-74] and known as the powerful tool for chip-based whole-cell biosensors [75]. "Surface display system" of magnetosomes used in immunoassay, enzyme reaction, and cell separation [76-87]. Magnetosomes can also be used as an effective model system to study CDF related II type diabetes [88]. Magnetotactic bacteria used to produce electricity and magnetic field induced rotation of magnetosome chains in silicified MTB [78, 89]. Thus, availability of high-quality magnetosomes will significantly increase potential applications, and it is therefore highly desirable and important to establish and develop rapid, simple, relatively inexpensive processes for yield cultivation of magnetosomes. 


\section{Conclusions}

The magnetosome production ability is of great interest in the areas of biotechnology, biomedicine, and environmental protection. The magnetosome formation is the outcome of the controlled biomineralization mechanisms and can be produced in different shapes and size ranges by magnetotatic bacteria. However, the need for more efficient cultivation methods for mass production of magnetosome represents the major obstacle to potential applications. For this purpose, various approaches have been developed and tested for such high-yield cultivation, including optimization of dissolved oxygen concentration, nutrient-balanced feeding strategies, and genetic engineering. Still, there remains an urgent need for further improved systems and optimization of conditions for enhancement of magnetosome yield at laboratory scale and mass-production (commercial or industrial) scale.

\section{Acknowledgements}

The authors are grateful to Dr. S. Anderson for English editing of the manuscript.

\section{Authors' contributions}

All author's contributed in writing, design and figures of this review. All authors read and approved the final manuscript.

\section{Funding}

This study was supported by National Natural Science Foundation of China (31570067), and Opening Project of the State Key Laboratory of Microbial Resources.

\section{Availability of data and materials}

Not applicable.

\section{Ethics approval and consent to participate}

Not applicable.

\section{Consent for publication}

Not applicable.

\section{Competing interests}

The authors declare no competing interests.

\begin{abstract}
Author details
${ }^{1}$ State Key Laboratory of Agro-Biotechnology, College of Biological Sciences, China Agricultural University, Beijing 100193, China. ${ }^{2}$ Department of Microbiology, Faculty of Life Sciences, University of Okara, Okara 56130, Pakistan. ${ }^{3}$ Beijing Key Laboratory for Prevention and Control of Infectious Diseases in Livestock and Poultry, Institute of Animal Husbandry and Veterinary Medicine, Beijing Academy of Agriculture and Forestry Sciences, Beijing, BJ, People's Republic of China.
\end{abstract}

Received: 8 August 2020 Accepted: 9 October 2020 Published online: 20 October 2020

\section{References}

1. McNamara K, Tofail SA. Nanoparticles in biomedical applications. Adv Phys. 2017;2(1):54-88.

2. Su C. Environmental implications and applications of engineered nanoscale magnetite and its hybrid nanocomposites: a review of recent literature. J Hazard Mater. 2017;322:48-84.
3. Jacob JJ, Suthindhiran K. Magnetotactic bacteria and magnetosomesScope and challenges. Mater Sci Eng C. 2016;68:919-28.

4. Bazylinski DA, Frankel RB. Magnetosome formation in prokaryotes. Nat Rev Microbiol. 2004;2(3):217-30.

5. Uebe R, Schüler D. Magnetosome biogenesis in magnetotactic bacteria. Nat Rev Microbiol. 2016;14(10):62.

6. Ke L, Chen Y, Liu P, Liu S, Wu D, Yuan Y, Wu Y, Gao M. Characteristics and optimised fermentation of a novel magnetotactic bacterium, Magnetospirillum sp. ME-1. FEMS Microbiol Lett. 2018;365(14):fny052.

7. Moisescu C, Ardelean I, Benning LG. The effect and role of environmental conditions on magnetosome synthesis. Front Microbiol. 2014;5:49.

8. Marcano L, García-Prieto A, Muñoz D, Barquín LF, Orue I, Alonso J, Muela A, Fdez-Gubieda ML. Influence of the bacterial growth phase on the magnetic properties of magnetosomes synthesized by Magnetospirillum gryphiswaldense. Biochim Biophys Acta. 2017;1861(6):1507-14.

9. Alphandéry E, Chebbi I, Guyot F, Durand-Dubief M. Use of bacterial magnetosomes in the magnetic hyperthermia treatment of tumours: A review. Int J Hyperth. 2013;29(8):801-9.

10. Postec A, Tapia N, Bernadac A, Joseph M, Davidson S, Wu LF, Ollivier B, Pradel N. Magnetotactic bacteria in microcosms originating from the French Mediterranean coast subjected to oil industry activities. Microb Ecol. 2012;63(1):1-1.

11. Shimoshige H, Kobayashi H, Mizuki T, Nagaoka Y, Inoue A, Maekawa T. Effect of polyethylene glycol on the formation of magnetic nanoparticles synthesized by Magnetospirillum magnetotacticum MS-1. PLoS ONE. 2015;10(5):e0127481.

12. Ali I, Peng C, Khan ZM, Naz I. Yield cultivation of magnetotactic bacteria and magnetosomes: a review. J Basic Microbiol. 2017;57(8):643-52.

13. Li J, Pan Y, Liu Q, Qin H, Deng C, Che R, Yang X. A comparative study of magnetic properties between whole cells and isolated magnetosomes of Magnetospirillum magneticum AMB-1. Chinese Sci Bull. 2010;55(1):38-44.

14. Araujo AC, Abreu F, Silva KT, Bazylinski DA, Lins U. Magnetotactic bacteria as potential sources of bioproducts. Mar Drugs. 2015;13(1):389-430.

15. Liu Y, Li GR, Guo FF, Jiang W, Li Y, Li L. Large-scale production of magnetosomes by chemostat culture of Magnetospirillum gryphiswaldense at high cell density. Microb Cell Fact. 2010;9(1):99.

16. Egli T, Zinn M. The concept of multiple-nutrient-limited growth of microorganisms and its application in biotechnological processes. Biotechnol Adv. 2003;22(1-2):35-43.

17. Zhang Y, Zhang X, Jiang W, Li Y, Li J. Semicontinuous culture of Magnetospirillum gryphiswaldense MSR-1 cells in an autofermentor by nutrientbalanced and isosmotic feeding strategies. Appl Environ Microbiol. 2011;77(17):5851-6.

18. Fernández-Castané A, Li H, Thomas OR, Overton TW. Development of a simple intensified fermentation strategy for growth of Magnetospirillum gryphiswaldense MSR-1: Physiological responses to changing environmental conditions. N biotechnol. 2018;46:22-30.

19. Yang C, Takeyama H, Matsunaga T. Iron feeding optimization and plasmid stability in production of recombinant bacterial magnetic particles by Magnetospirillum magneticum AMB-1 in fed-batch culture. J Biosci Bioeng. 2001;91(2)(a):213-6.

20. Yang CD, Takeyama H, Tanaka T, Matsunaga T. Effects of growth medium composition, iron sources and atmospheric oxygen concentrations on production of luciferase-bacterial magnetic particle complex by a recombinant Magnetospirillum magneticum AMB-1. Enzyme Microb Technol. 2001;29(1):13-9.

21. $\mathrm{ICH}$. ICH Q3D guidelines, in International Conference on Harmonization (ICH), EMA/CHMP/ICH/353369/2013. London, UK: Committee for Human Medicinal Products; 2019.

22. Berny C, Le Fèvre R, Guyot F, Blondeau K. Guizonne C. Rousseau E, Bayan $\mathrm{N}$, Alphandéry $\mathrm{E}$. A method for producing highly pure magnetosomes in large quantity for medical applications using Magnetospirillum gryphiswaldense MSR-1 magnetotactic bacteria amplified in minimal growth media. Front Bioeng Biotechnol. 2020:8:16.

23. Jajan LH, Hosseini SN, Ghorbani M, Mousavi SF, Ghareyazie B, Abolhassani M. Effects of environmental conditions on high-yield magnetosome production by Magnetospirillum gryphiswaldense MSR-1. Iran Biomed J. 2019;23(3):209.

24. Sun JB, Zhao F, Tang T, Jiang W, Tian JS, Li Y, Li JL. High-yield growth and magnetosome formation by Magnetospirillum gryphiswaldense MSR-1 in 
an oxygen-controlled fermentor supplied solely with air. Appl Microbiol Biotechnol. 2008;79(3):389.

25. Heyen U, Schüler D. Growth and magnetosome formation by microaerophilic Magnetospirillum strains in an oxygen-controlled fermentor. Appl Microbiol Biotechnol. 2003;61(5-6):536-44.

26. Rong C, Zhang C, Zhang Y, Qi L, Yang J, Guan G, Li Y, Li J. FeoB2 functions in magnetosome formation and oxidative stress protection in Magnetospirillum gryphiswaldense strain MSR-1. J Bacteriol. 2012;194(15):3972-6.

27. Guo FF, Yang W, Jiang W, Geng S, Peng T, Li JL. Magnetosomes eliminate intracellular reactive oxygen species in Magnetospirillum gryphiswaldense MSR-1. Environ Microbiol. 2012;14(7):1722-9.

28. Bonora M, Patergnani S, Rimessi A, De Marchi E, Suski JM, Bononi A, Giorgi C, Marchi S, Missiroli S, Poletti F, Wieckowski MR. ATP synthesis and storage. Puri Signal. 2012;8(3):343-57.

29. Ban J, Jiang W, Li Y, Zhang Y, Li J. Functional analysis of hydrogenases and their effects on cell growth and magnetosome synthesis in Magnetospirillum gryphiswaldense. Chinese Sci Bull. 2010;55(13):1271-7.

30. Yang J, Li S, Huang X, Tang T, Jiang W, Zhang T, Li Y. A key time point for cell growth and magnetosome synthesis of Magnetospirillum gryphiswaldense based on real-time analysis of physiological factors. Front Microbiol. 2013;4:210

31. Liu J, Ding Y, Jiang W, Tian J, Li Y, Li J. A mutation upstream of an ATPase gene significantly increases magnetosome production in Magnetospirillum gryphiswaldense. Appl Microbiol Biotechnol. 2008;81(3):551-8.

32. Cabiscol Català E, Tamarit Sumalla J, Ros SJ. Oxidative stress in bacteria and protein damage by reactive oxygen species. Int Microbiol. 2000;3:3-8.

33. Imlay JA. Pathways of oxidative damage. Annu Rev Microbiol. 2003;57(1):395-418

34. Gao L, Zhuang J, Nie L, Zhang J, Zhang Y, Gu N, Wang T, Feng J, Yang D, Perrett S, Yan X. Intrinsic peroxidase-like activity of ferromagnetic nanoparticles. Nat Nanotechnol. 2007;2(9):577-83.

35. Xiang Z, Yang X, Xu J, Lai W, Wang Z, Hu Z, Tian J, Geng L, Fang Q. Tumor detection using magnetosome nanoparticles functionalized with a newly screened EGFR/HER2 targeting peptide. Biomaterials. 2017;115:53-64.

36. Guo F, Liu Y, Chen Y, Tang T, Jiang W, Li Y, Li J. A novel rapid and continuous procedure for large-scale purification of magnetosomes from Magnetospirillum gryphiswaldense. Appl Microbiol Biotechnol. 2011;90(4):1277-83.

37. Prozorov T, Bazylinski DA, Mallapragada SK, Prozorov R. Novel magnetic nanomaterials inspired by magnetotactic bacteria: Topical review. Material Sci Eng R Rep. 2013;74(5):133-72.

38. Hamdous Y, Chebbi I, Mandawala C, Le Fèvre R, Guyot F, Seksek O, Alphandéry E. Biocompatible coated magnetosome minerals with various organization and cellular interaction properties induce cytotoxicity towards RG-2 and GL-261 glioma cells in the presence of an alternating magnetic field. J Nanobiotech. 2017;15(1):74.

39. Mandawala C, Chebbi I, Durand-Dubief M, Le Fèvre R, Hamdous Y, Guyot F, Alphandéry E. Biocompatible and stable magnetosome minerals coated with poly-l-lysine, citric acid, oleic acid, and carboxy-methyl-dextran for application in the magnetic hyperthermia treatment of tumors. J Materials Chem B. 2017;5(36):7644-60.

40. Sun JB, Duan JH, Dai SL, Ren J, Zhang YD, Tian JS, Li Y. In vitro and in vivo antitumor effects of doxorubicin loaded with bacterial magnetosomes (DBMs) on H22 cells: the magnetic bio-nanoparticles as drug carriers. Cancer Lett. 2007;258(1):109-17.

41. Mannucci S, Ghin L, Conti G, Tambalo S, Lascialfari A, Orlando T, Benati D, Bernardi P, Betterle N, Bassi R, Marzola P. Magnetic nanoparticles from Magnetospirillum gryphiswaldense increase the efficacy of thermotherapy in a model of colon carcinoma. PLoS ONE. 2014;9(10):e108959.

42. Sangnier AP, Preveral S, Curcio A, Silva AK, Lefèvre CT, Pignol D, Lalatonne $Y$, Wilhelm C. Targeted thermal therapy with genetically engineered magnetite magnetosomes@ RGD: Photothermia is far more efficient than magnetic hyperthermia. J Contr Release. 2018;279:271-81.

43. Mickoleit F, Borkner CB, Toro-Nahuelpan M, Herold HM, Maier DS, Plitzko JM, Scheibel T, Schüler D. In vivo coating of bacterial magnetic nanoparticles by magnetosome expression of spider silk-inspired peptides. Biomacromology. 2018;19(3):962-72.

44. Deng Q, Liu Y, Wang S, Xie M, Wu S, Chen A, Wu W. Construction of a novel magnetic targeting anti-tumor drug delivery system: cytosine arabinoside-loaded bacterial magnetosome. Materials. 2013;6(9):3755-63.
45. Tang YS, Wang D, Zhou C, Ma W, Zhang YQ, Liu B, Zhang S. Bacterial magnetic particles as a novel and efficient gene vaccine delivery system. Gene Ther. 2012;19(12):1187-95.

46. Alphandéry E, Abi Haidar D, Seksek O, Guyot F, Chebbi I. Fluorescent magnetosomes for controlled and repetitive drug release under the application of an alternating magnetic field under conditions of limited temperature increase $\left(<2.5^{\circ} \mathrm{C}\right)$. Nanoscale. 2018;10(23):10918-33.

47. Geng Y, Wang J, Wang X, Liu J, Zhang Y, Niu W, Basit A, Liu W, Jiang W. Growth-inhibitory effects of anthracycline-loaded bacterial magnetosomes against hepatic cancer in vitro and in vivo. Nanomedicine. 2019;14(13):1663-80.

48. Wang J, Geng Y, Zhang Y, Wang X, Liu J, Basit A, Miao T, Liu W, Jiang W. Bacterial magnetosomes loaded with doxorubicin and transferrin improve targeted therapy of hepatocellular carcinoma. Nanotheranostics. 2019;3(3):284.

49. Felfoul O, Mohammadi M, Taherkhani S, De Lanauze D, Xu YZ, Loghin D, Essa S, Jancik S, Houle D, Lafleur M, Gaboury L. Magneto-aerotactic bacteria deliver drug-containing nanoliposomes to tumour hypoxic regions. Nat Nanotechnol. 2016;11(11):941-7.

50. Cheng L, Ke Y, Yu S, Jing J. Co-delivery of doxorubicin and recombinant plasmid pHSP70-PIk1-shRNA by bacterial magnetosomes for osteosarcoma therapy. Int J Nanomed. 2016;11:5277.

51. Dai Q, Long R, Wang S, Kankala RK, Wang J, Jiang W, Liu Y. Bacterial magnetosomes as an efficient gene delivery platform for cancer theranostics. Microb Cell Fact. 2017;16(1):1-9.

52. Wang $X$, Wang JG, Geng YY, Wang JJ, Zhang XM, Yang SS, Jiang W, Liu WQ. An enhanced anti-tumor effect of apoptin-cecropin B on human hepatoma cells by using bacterial magnetic particle gene delivery system. Biochem Biophys Res Commun. 2018;496(2):719-25.

53. Xiang L, Bin W, Huali J, Wei J, Jiesheng T, Feng G, Ying L. Bacterial magnetic particles (BMPs)-PEl as a novel and efficient non-viral gene delivery system. The Journal of Gene Medicine: A cross-disciplinary journal for research on the science of gene transfer and its clinical applications. J Gene Med. 2007;9(8):679-90.

54. Alphandery E, Faure S, Seksek O, Guyot F, Chebbi I. Chains of magnetosomes extracted from AMB-1 magnetotactic bacteria for application in alternative magnetic field cancer therapy. ACS Nano. 2011;5(8):6279-96.

55. Alphandéry E, Idbaih A, Adam C, Delattre JY, Schmitt C, Guyot F, Chebbi I. Development of non-pyrogenic magnetosome minerals coated with poly-I-lysine leading to full disappearance of intracranial U87-Luc glioblastoma in $100 \%$ of treated mice using magnetic hyperthermia. Biomaterials. 2017;141:210-22.

56. Mannucci S, Tambalo S, Conti G, Ghin L, Milanese A, Carboncino A, Nicolato E, Marinozzi MR, Benati D, Bassi R, Marzola P. Magnetosomes extracted from Magnetospirillum gryphiswaldense as theranostic agents in an experimental model of glioblastoma. Contrast Media Mol I. 2018;2018.

57. Boucher M, Geffroy F, Prévéral S, Bellanger L, Selingue E, AdryanczykPerrier G, Pean M, Lefèvre CT, Pignol D, Ginet N, Mériaux S. Genetically tailored magnetosomes used as MRI probe for molecular imaging of brain tumor. Biomaterials. 2017;121:167-78.

58. Orlando T, Mannucci S, Fantechi E, Conti G, Tambalo S, Busato A, Innocenti C, Ghin L, Bassi R, Arosio P, Orsini F. Characterization of magnetic nanoparticles from Magnetospirillum gryphiswaldense as potential theranostics tools. Contrast Media Mol I. 2016;11(2):139-45.

59. Arakaki A, Nakazawa H, Nemoto M, Mori T, Matsunaga T. Formation of magnetite by bacteria and its application. J R Soc Interface. 2008:5(26):977-99.

60. Schwarz S, Fernandes F, Sanroman L, Hodenius M, Lang C, Himmelreich U, Schmitz-Rode T, Schueler D, Hoehn M, Zenke M, Hieronymus T. Synthetic and biogenic magnetite nanoparticles for tracking of stem cells and dendritic cells. J Magn Magn Mater. 2009;321(10):1533-8.

61. Xu J, Hu J, Liu L, Li L, Wang X, Zhang H, Jiang W, Tian J, Li Y, Li J. Surface expression of protein $\mathrm{A}$ on magnetosomes and capture of pathogenic bacteria by magnetosome/antibody complexes. Front Microbiol. 2014;5:136.

62. Chen JF, Li Y, Wang ZF, Li JL, Jiang W, Li SH. High-sensitivity detection of fruit tree viruses using bacterial magnetic particles. J Integr Plant Biol. 2009;51(4):409-13.

63. Li A, Zhang H, Zhang X, Wang Q, Tian J, Li Y, Li J. Rapid separation and immunoassay for low levels of Salmonella in foods using 
magnetosome-antibody complex and real-time fluorescence quantitative PCR. J Sep Sci. 2010;33(21):3437-43.

64. Hideshima S, Yanagisawa M, Arakaki A, Matsunaga T, Osaka T. Quantitative Detection of immunoreaction using magnetite nanoparticles and Raman scattering spectroscopy. e-J Surf Sci Nanotech. 2008;6:142-6.

65. Matsunaga T, Maeda Y, Yoshino T, Takeyama H, Takahashi M, Ginya H, Aasahina J, Tajima H. Fully automated immunoassay for detection of prostate-specific antigen using nano-magnetic beads and micro-polystyrene bead composites,'Beads on Beads'. Anal Chim Acta. 2007;597(2):331-9.

66. Wacker R, Ceyhan B, Alhorn P, Schueler D, Lang C, Niemeyer CM. Magneto immuno-PCR: a novel immunoassay based on biogenic magnetosome nanoparticles. Biophys Res Commun. 2007;357(2):391-6.

67. Sode K, Kudo S, Sakaguchi T, Nakamura N, Matsunaga T. Application of bacterial magnetic particles for highly selective mRNA recovery system. Biotechnol Tech. 1993; 7(9):688-94.

68. Tanaka T, Maruyama K, Yoda K, Nemoto E, Udagawa Y, Nakayama H, Takeyama H, Matsunaga T. Development and evaluation of an automated workstation for single nucleotide polymorphism discrimination using bacterial magnetic particles. Biosensors Bioelectron. 2003;19(4):325-30.

69. Tanaka M, Arakaki A, Staniland SS, Matsunaga T. Simultaneously discrete biomineralization of magnetite and tellurium nanocrystals in magnetotactic bacteria. Appl Environ Microbiol. 2010;76(16):5526-32.

70. Roda A, Cevenini L, Borg S, Michelini E, Calabretta MM, Schüler D. Bioengineered bioluminescent magnetotactic bacteria as a powerful tool for chip-based whole-cell biosensors. Lab Chip. 2013;13(24):4881-9.

71. Bahaj AS, James PA, Moeschler FD. Low magnetic-field separation system for metal-loaded magnetotactic bacteria. J Magn Magn Mater 1998;177:1453-4.

72. Zhou Y, Lisowski W, Zhou Y, Jern NW, Huang K, Fong E. Genetic improvement of Magnetospirillum gryphiswaldense for enhanced biological removal of phosphate. Biotechnol Lett. 2017:39(10):1509-14.

73. Tanaka M, Brown R, Hondow N, Arakaki A, Matsunaga T, Staniland $\mathrm{S}$. Highest levels of $\mathrm{Cu}, \mathrm{Mn}$ and $\mathrm{Co}$ doped into nanomagnetic magnetosomes through optimized biomineralisation. J Mater Chem. 2012;22(24):11919-21.

74. Tanaka M, Knowles W, Brown R, Hondow N, Arakaki A, Baldwin S, Staniland $S$, Matsunaga T. Biomagnetic recovery and bioaccumulation of selenium granules in magnetotactic bacteria. Appl Environ Microbiol. 2016;82(13):3886-91.

75. Sugamata Y, Uchiyama R, Honda T, Tanaka T, Matsunaga T, Yoshino T. Functional expression of thyroid-stimulating hormone receptor on nano-sized bacterial magnetic particles in Magnetospirillum magneticum AMB-1. Int J Mol Sci. 2013;14(7):14426-38.

76. Honda T, Yasuda T, Tanaka T, Hagiwara K, Arai T, Yoshino T. Functional expression of full-length TrkA in the prokaryotic host Magnetospirillum magneticum AMB-1 by using a magnetosome display system. Appl Environ Microbiol. 2015:81(4):1472-6.

77. Goldhawk DE, Rohani R, Sengupta A, Gelman N, Prato FS. Using the magnetosome to model effective gene-based contrast for magnetic resonance imaging. Wiley Interdisciplinary Reviews: Nanomed Nanobiotechnol. 2012:4(4):378-88.

78. Smit BA, Van Zyl E, Joubert JJ, Meyer W, Prévéral S, Lefevre CT, Venter SN Magnetotactic bacteria used to generate electricity based on Faraday's law of electromagnetic induction. Lett Appl Microbiol. 2018;66(5):362-7.
79. Matsunaga T, Kamiya S. Use of magnetic particles isolated from magnetotactic bacteria for enzyme immobilization. Appl Microbiol Biotechnol. 1987:26(4):328-32.

80. Yoshino T, Hirabe H, Takahashi M, Kuhara M, Takeyama H, Matsunaga T. Magnetic cell separation using nano-sized bacterial magnetic particles with reconstructed magnetosome membrane. Biotechnol Bioeng. 2008:101(3):470-7.

81. Takahashi M, Yoshino T, Matsunaga T. Surface modification of magnetic nanoparticles using asparagines-serine polypeptide designed to control interactions with cell surfaces. Biomaterials. 2010;31(18):4952-7.

82. Grouzdev DS, Dziuba MV, Kurek DV, Ovchinnikov Al, Zhigalova NA, Kuznetsov BB, Skryabin KG. Optimized method for preparation of IgGbinding bacterial magnetic nanoparticles. Plos One. 2014;9(10):e109914.

83. Yoshino T, Kaji C, Matsunaga T. Bioengineering of bacterial magnetic particles and its application to estrogen receptor-ligand binding assay. MRS Online Proceedings Library Arch. 2008;1094.

84. Sugamata Y, Tanaka T, Matsunaga T, Yoshino T. Functional expression of an scFv on bacterial magnetic particles by in vitro docking. Biochem Biophys Res Commun. 2014;445(1):1-5.

85. Maeda Y, Yoshino T, Takahashi M, Ginya H, Asahina J, Tajima H, Matsunaga T. Noncovalent immobilization of streptavidin on in vitro-and in vivo-biotinylated bacterial magnetic particles. Appl Environ Microbiol. 2008;74(16):5139-45.

86. Matsunaga T, Arakaki A, Takahoko M. Preparation of luciferase-bacterial magnetic particle complex by artificial integration of MagA-luciferase fusion protein into the bacterial magnetic particle membrane. Biotechnol Bioeng. 2002;77(6):614-8.

87. Takahashi M, Yoshino T, Matsunaga T. Surface modification of magnetic nanoparticles using asparagines-serine polypeptide designed to control interactions with cell surfaces. Biomaterials. 2010;31(18):4952-7.

88. Zeytuni N, Uebe R, Maes M, Davidov G, Baram M, Raschdorf O, Friedler A, Miller Y, Schüler D, Zarivach R. Bacterial magnetosome biomineralizationa novel platform to study molecular mechanisms of human CDF-related Type-II diabetes. PLoS One. 2014;9(5):e97154.

89. Blondeau M, Guyodo Y, Guyot F, Gatel C, Menguy N, Chebbi I, Haye B, Durand-Dubief M, Alphandéry E, Brayner R, Coradin T. Magnetic-field induced rotation of magnetosome chains in silicified magnetotactic bacteria. Sci Rep. 2018;8(1):1-9.

90. Matsunaga T, Tsujimura N, Kamiya S. Enhancement of magnetic particle production by nitrate and succinate fed-batch culture of Magnetospirillum sp. AMB-1. Biotechnol Tech. 1996;10:495-500.

91. Yang J, Li S, Huang X, Tang T. A key time point for cell growth and magnetosome synthesis of Magnetospirillum gryphiswaldense based on real-time analysis of physiological factors. Front Microbiol. 2013;4:210.

\section{Publisher's Note}

Springer Nature remains neutral with regard to jurisdictional claims in published maps and institutional affiliations.

Ready to submit your research? Choose BMC and benefit from:

- fast, convenient online submission

- thorough peer review by experienced researchers in your field

- rapid publication on acceptance

- support for research data, including large and complex data types

- gold Open Access which fosters wider collaboration and increased citations

- maximum visibility for your research: over 100M website views per year

At BMC, research is always in progress.

Learn more biomedcentral.com/submissions 